\begin{tabular}{|c|c|c|c|c|}
\hline JURNAL & \multirow{2}{*}{ NOLUME 3} & \multirow{2}{*}{ NOMOR 1} & HALAMAN 65-74 & $\begin{array}{l}\text { ISSN 2655-8823 }(p) \\
\text { ISSN 2656-1786 }(e)\end{array}$ \\
\hline
\end{tabular}

\title{
ANALISIS KONFLIK DISTRIBUSI BANTUAN SOSIAL COVID-19 DAN STRATEGI PENYELESAIAN KONFLIK DI KOTA BANDUNG
}

\author{
Khofiyya Fathimah A.F \\ Prodi Ilmu Kesejahteraan Sosial FISIP Universitas Padjadjaran \\ E-mail: khofiyya17001@mail.unpad.ac.id \\ Soni Akhmad Nulhaqim \\ Departemen Kesejahteraan Sosial FISIP Universitas Padjadjaran \\ E-mail: soni.nulhaqim@unpad.ac.id
}

\begin{abstract}
ABSTRAK
Kebijakan pemerintah dalam menangani pandemi Covid-19 sangat memepngaruhi perekonomian masyarakat, terutama semenjak diberlakukan Pembatasan Sosial Berskala Besar (PSBB) dan lockdown di beberapa negara. Banyaknya masyarakat Indonesia yang bekerja di sektor informal, serta adanya PHK oleh sejumlah perusahaan kepada karyawannya, maysarakat yang tergolong ke dalam kelas menengah ke bawah banyak mengalami kehilangan penghasilan mereka. Karena hal tersebut, pemerintah bertanggung jawab untuk memfasilitasi kebutuhan pangan yang mereka selama dalam masa kebijakan PSBB yang diterapkan oleh pemerintah. Pemerintah memastikan bahwa setiap warganya tetap mendapatkan hak untuk hidup sekalipun dalam kondisi pandemi Covid-19. Distribusi bantuan sosial Covid-19 ternyata menimbulkan konflik ditengah masyarakat karena distribusi yang tidak tepat sasaran. Dalam memahami konflik tersebut, artikel ini mengkaji konflik distribusi bantuan sosial dengan menggunakan alat bantu pohon konflik dan strategi dalam mengelola konflik tersebut dengan memetakan jalan terbuka.
\end{abstract}

Kata kunci: konflik, Covid-19, pohon konflik, strategi mengelola konflik.

\section{PENDAHULUAN}

Pada awal tahun 2020, dunia digemparkan dengan merebaknya virus baru yaitu Coronavirus jenis baru (SARSCoV-2) dan penyakitnya disebut Coronavirus Disease 2019 (Covid-19). Diketahui virus ini berasal dari Wuhan, Provinsi Hubei, Tiongkok (Yuliana, 2020). Kemudian pada 12 Maret 2020, WHO mengumumkan Covid-19 sebagai pandemik. Di Indonesia, Covid-19 telah masuk sejak akhir Januari 2020 (Kumparan.com, 2020). Hal ini didukung oleh data Dinas Kesehatan DKI Jaktarta dan Kementrian Kesehatan bahwa pada layanan kesehatan terdapat kenaikan orang dengan gejala kasus Covid-19 seperti demam, batuk, dan sesak napas. Menurut WHO (2020) (dalam Susilo, et.al, 2020) virus ini dapat ditularkan dari manusia ke manusia dan telah menyebar secara luas di China dan lebih dari 190 negara dan teritori lainnya. Hingga tanggal 26 November 2020 , terdapat 616.753 kasus dengan positif dan 16.352 jumlah kematian di Indonesia (TribunTernate.com, 2020).

Dalam upaya pencegahan penyebaran Covid-19 di Indonesia, pemerintah telah melakukan beberapa kebijakan antara lain seperti menetapkan wabah virus Covid-19 ini sebagai bencana nasional melalui Keputusan Presiden Republik Indonesia Nomor 2 Tahun 2020 tentang Penetapan Bencana Non-Alam Penyebaran Corona Virus Disease 2019 (Covid-19) sebagai bencana nasional. Pemerintah juga menerapkan Pembatasan Sosial Berskala Besar (PSBB) untuk daerah-daerah yang termasuk ke dalam zona merah melalui peraturan Menteri Kesehatan (Permenkes) Nomor 9 Tahun 2020 tentang Pedoman PSBB (Arifin, 2020) (dalam Rahmansyah, et.al, 2020). Selain itu, Kementrian Pendidikan dan Kebudayaan juga menerbitkan Surat Edaran Nomor 4 Tahun 2020 tentang Pelaksanaan Pendidikan Dalam Masa Darurat Coronavirus Disease (Covid-19) (Kemendikbud, 2020). Kemudian, di sektor transportasi seperti 


\begin{tabular}{|c|c|c|c|c|}
\hline $\begin{array}{c}\text { JURNAL } \\
\text { KOLABORASI RESOLUSI KONFLIK }\end{array}$ & \multirow{2}{*}{ VOLUME 3} & \multirow{2}{*}{ NOMOR 1 } & HALAMAN 65-74 & $\begin{array}{l}\text { ISSN 2655-8823 }(p) \\
\text { ISSN 2656-1786 }(e)\end{array}$ \\
\hline
\end{tabular}

halnya transportasi online (ojek online) mereka dilarang membawa penumpang, mereka hanya boleh mengantarkan barang. Di sektor perekonomian banyak pertokoan dipaksa untuk menutup toko mereka dan apabila tidak menutup toko, maka mereka akan dikenai denda (Mufida, 2020).

Adanya pemberlakuan Pembatasan Sosial Berskala Besar (PSBB) di beberapa wilayah yang termasuk ke dalam zona merah, ini menyebabkan dampak yang cukup signifikan terhadap kelangsungan kehidupan masyarakat karena interaksi antar masyarakat menjadi terbatasi yang menyebabkan aktivitas perekonomian terganggu, pekerjaan harian menjadi tidak bisa dilakukan, banyaknya pemutusan hubungan kerja (PHK) oleh sejumlah perusahaan karena ketidakmampuan perusahaan dalam mempertahankan karyawannya dalam situasi pandemi. Dampak Covid-19 kepada perekonomian secara empiris dialami oleh seluruh lapisan masyarakat, akan tetapi keluarga dari kelompok menengah ke bawah merasakan dampak yang jauh lebih besar, mengingat sebagian besarnya merupakan para pekerja sektor informal yang banyak menggantungkan hidup kepada mata pencaharian harian (Herdiana, 2020). Apabila hal ini terus dibiarkan, maka akan berdampak terhadap angka kemiskinan masyarakat yang meningkat disebabkan banyaknya keluarga dari kelompok ekonomi menengah ke bawah yang tidak dapat mencari nafkah bagi keberlangsungan hidupnya dalam situasi pandemi ini.

Dalam menghadapi situasi pandemik ini, pemerintah segera melakukan penanganan terhadap kemunduran ekonomi yang dialami oleh masyarakat. Pemerintah mengeluarkan kebijakan keuangan sebagai upaya dalam menghadapi Covid-19 bagi keluarga dari kelompok menengah ke bawah yang terdampak Covid-19, baik yang berasal dari pemerintah pusat maupun yang berasal dari pemerintah daerah. Bantuan yang diberikan oleh pemerintah yaitu berupa bantuan sosial yang diberikan kepada keluarga yang terdampak oleh Covid-19. Adanya kebijakan bantuan sosial yang diberikan oleh pemerintah diharapkan mampu membantu masyarakat miskin yang terdampak Covid-19 agar tetap dapat menjalankan kehidupannya. Pemberian bantuan sosial oleh pemerintah yang diberikan kepada masyarakat, bukan merupakan hal baru. Dalam situasi bencana disuatu wilayah, baik pemerintah pusat maupun pemerintah daerah seringkali memberikan bantuan sosial kepada masyarakat. Namun, respon masyarakat terhadap realisasi yang terjadi masih banyak menimbulkan kekecewaan terhadap masyarakat.

Pelaksanaan program bantuan sosial tidak sepenuhnya berjalan sebagaimana tujuan awal yang telah ditetapkan, dalam pelaksanaannya masalah timbul yaitu program tersebut tidak tepat sasaran. Kegiatan rutin yang diberikan kepada masyarakat dilakukan sesuai dengan tingkat kemiskinan masyakarat sebagai penerima bantuan sosial dalam bentuk yang beragam. Di masa pandemi Covid-19, pemerintah, baik pusat maupun daerah, kelimpungan dalam penyaluran bantuan sosial kepada masyarakat (Ihsanuddin, 2020) (dalam Rahmansyah, et.al, 2020). Menurut Setiawan (2020) (dalam Herdiana, 2020) sedangkan masyarakat yang tidak termasuk miskin dan tidak berhak mendapatkan bantuan sosial justru secara empiris mendapatkan bantuan sosial dari pemerintah. Dalam pemberian bantuan sosial yang dilakukan oleh pemerintah baik pusat maupun daerah terkesan membingungkan, lambat diterima, dan tidak tepat sasaran (dalam Rahmansyah, et.al, 2020).

Dalam kondisi pandemik Covid-19 ini, terdapat sembilan jenis bantuan yang dibagikan kepada masyarakat diantaranya bantuan sosial presiden, bantuan sosial provinsi, bantuan sosial kabupaten/kota, hingga dana desa. Di Jawa Barat sendiri, data penerima bantuan sosial itu dinilai tumpang tindih lantaran selain menerima bantuan sosial pemprov, ada pula warga 


\begin{tabular}{|c|c|c|c|c|}
\hline JURNAL & \multirow{2}{*}{ VOLUME 3} & \multirow{2}{*}{ NOMOR 1 } & HALAMAN 65-74 & $\begin{array}{l}\text { ISSN 2655-8823 }(p) \\
\text { ISSN 2656-1786 }(e)\end{array}$ \\
KOLABORASI RESOLUSI KONFLIK & ISS \\
\hline
\end{tabular}

yang terdaftar sebagai penerima Program Keluarga Harapan (PKH), Keluarga Penerima Manfaat (KPM), dan jenis bantuan lainnya (CNN Indonesia, 2020). Banyaknya jenis bantuan ini kemudian mencuat ke permukaan soal kekecewaan, penolakan, kecemburuan sosial, hingga rasa ketidakadilan. Dalam hal ini, Gubernur Jawa Barat Ridwan Kamil membenarkan hal tersebut pasalnya terdapat kekeliruan dalam data Keluarga Rumah Tangga Sasaran (KRTS) dan perlu diperbaiki (Halim and Mukti 2020; Humas Provinsi Jawa Barat 2020) (dalam Herdiana. 2020).

Di Kota Bandung sendiri, validasi data menjadi permasalahan yang serius dalam memberikan bantuan sosial kepada masyarakat yang terdampak Covid-19. Pasalnya, menurut Dinas Sosial dan Penanggulangan Kemiskinan (Dinsosnangkis) Kota Bandung tercatat sebanyak 238.000 orang terdampak pandemi Covid-19 secara ekonomi yang dikategorikan ke dalam miskin baru dan penerima bantuan sosial dari pemerintah (PR Bandung Raya, 2020). Namun, berdasarkan temuan di lapangan menunjukkan banyak data yang tidak memenuhi kriteria, bahkan ada yang mengaku menjadi masyarakat miskin demi mendapatkan bantuan sosial. Beberapa kasus lainnya, seperti penerima telah pindah alamat atau orang sudah meninggal masih tercatat sebagai penerima bantuan sosial (PR Bandung Raya, 2020). Melihat permasalahan tersebut, maka perlu adanya tindak lanjut dari Dinsosnangkis untuk melakukan validasi data bagi masyarakat yang berhak mendapatkan bantuan sosial dari pemerintah. Apabila terus dibiarkan, maka akan timbul permasalahan konflik di masyarakat dengan pemerintah.

Maka, berdasarkan pada permasalahan diatas, penulis akan melakukan analisis terhadap konflik yang ada dengan menggunakan alat bantu analisis konflik yaitu pohon konflik. Alat bantu ini digunakan untuk mengidentifikasi apa permasalahan intinya, apa penyebab masalah tersebut, dan bagaimana dampak yang ditimbulkan dari masalah tersebut. Alat bantu ini digunakan untuk mempermudah dalam melihat konflik secara kesuluruhan agar dapat memudahkan dalam memahami konflik tersebut serta dalam melakukan pemecahan masalah. Selanjutnya, strategi penyelesaian konflik juga diperlukan untuk membantu dalam memudahkan pemecahan masalah tersebut.

\section{METODE PENELITIAN}

Metode yang digunakan dalam penulisan artikel ini menggunakan studi pustaka yaitu metode pengumpulan data yang diarahkan kepada pencarian data dan informasi melalui dokumen-dokumen, baik dokumen tertulis, foto-foto, gambar, maupun dokumen elektronik yang dapat mendukung dalam proses penulisan. Jenis data yang digunakan penulis dalam artikel ini adalah data sekunder yaitu data yang diperoleh dari jurnal, buku dokumentasi, dan internet.

a. Dokumentasi

Dokumentasi merupakan metode untuk mencari dokumen atau datadata yang dianggap penting melalui artikel koran/majalah, jurnal, pustaka, brosur, buku dokumentasi serta melalui media elektronik yaitu internet, yang ada kaitannya dengan diterapkannya penelitian ini.

b. Studi Literatur

Studi literatur adalah cara yang dipakai untuk menghimpun datadata atau sumber-sumber yang berhubungan dengan topik yang diangkat dalam artikel. Studi literatur bisa didapat dari berbagai sumber, jurnal, buku dokumentasi, internet dan pustaka mengenai topik polemik bantuan sosial di tengah pandemi Covid-19.

\section{TINJAUAN KONSEPTUAL}

\section{a. Alat Bantu Konflik}

Dalam memahami konflik, kita perlu melakukan analisis konflik. Analisis konflik bertujuan untuk memahami latar 


\begin{tabular}{|c|c|c|c|c|}
\hline $\begin{array}{c}\text { JURNAL } \\
\text { KOLABORASI RESOLUSI KONFLIK }\end{array}$ & \multirow{2}{*}{ VOLUME 3} & \multirow{2}{*}{ NOMOR 1 } & HALAMAN 65-74 & $\begin{array}{l}\text { ISSN 2655-8823 }(p) \\
\text { ISSN 2656-1786 }(e)\end{array}$ \\
\hline
\end{tabular}

belakang atau sejarah suatu situasi dan kejadian-kejadian, untuk mengidentifikasi semua kelompok yang terlibat, untuk memahami pandangan semua kelompok dan lebih mengetahui bagaimana hubungan satu sama lain, dan untuk mengidentifikasi faktor-faktor dan kecenderungankecenderungan yang mendasari konflik (Fisher, et.al, 2001). Dalam menganalisis konflik, digunakan pula alat bantu konflik untuk memahami konflik dari berbagai tipe konflik yang ada. Dalam banyak kasus, alat bantu ini digunakan oleh kelompokkelompok sesuai dengan kebutuhan khusus mereka dalam menganalisis konflik.

Alat bantu yang akan digunakan dalam menganalisis konflik distribusi bantuan sosial Covid-19 ini ialah menggunakan alat bantu pohon konflik. Pohon konflik merupakan suatu alat bantu menggunakan gambar sebuah pohon untuk mengurutkan isu-isu konflik. Alat bantu pohon konflik ini bertujuan untuk merangsang diskusi tentang berbagai sebab dan efek dalam suatu konflik, untuk membantu kelompok menyepakati masalah inti, untuk membantu suatu kelompok atau tim dalam mengambil keputusan tentang prioritas untuk mengatasi berbagai berbagai isu konflik, dan untuk menghubungkan berbagai sebab dan efek satu sama lain dan untuk memfokuskan organisasinya (Fisher, et.al, 2001). Pohon konflik menyajikan suatu metode bagi suatu tim, kelompok, organisasi, atau masyarakat untuk mengidentifikasi isu-isu yang masingmasing dipandang penting dan selanjutnya dipisahkan ke dalam tiga kategori: (1) masalah-masalah inti, (2) penyebab, dan (3) berbagai efeknya.

Alat bantu pohon konflik ini digunakan sebagai dasar untuk mengetahui apa masalah inti, penyebab, dan efek yang ditimbulkan dari adanya distribusi bantuan sosial Covid-19. Pohon konflik dapat membantu untuk memetakan penyebab dari permasalahan yang ada di lapangan dan juga bagaimana dampak yang ditimbulkan dari konflik bantuan sosial Covid-19. Hal ini berguna untuk memudahkan dalam memahami konflik dan memudahkan dalam upaya pemecahan masalah agar jelas dan terbuka bagaimana konflik ini dapat bermula dan muncul ke permukaan.

\section{b. Strategi untuk Mengelola Konflik}

Dalam membuat strategi, kita perlu mempelajari situasi konflik yang ada. Analisisndapat dilakukan untuk dapat mengungkapkan kemungkinan tindakan yang dapat dilakukan. Setiap orang dan kelompok akan memiliki peluang tertentu bergantung pada posisinya dalam situasi tersebut dan kemampuan yang dimilikinya. Alat bantu untuk melakukan analisis mengungkapkan aspek-aspek masalah yang nantinya akan dijadikan sebagai dasar dalam menyusun strategi. Dalam menyusun strategi, selalu ada individu, organisasi, dan lembaga yang terlibat dengan suatu atau beberapa cara kegiatan yang mendukung transformasi konflik dan mengembangkan perdamaian. Dalam menyusun strategi, kita perlu melihat alat bantu yang digunakan dalam proses pengkajian konflik. Strategi juga digunakan dengan langkah yang secara berurutan agar tidak terjadi ambigu dalam memahami konflik.

Strategi yang akan digunakan dalam konflik ini yaitu dengan menggunakan memetakan jalan terbuka. Memetakan jalan terbuka merupakan alat untuk mengadaptasi peta konflik untuk mengetahui apa yang akan dilakukan selanjutnya. Hal ini bertujuan untuk mengidentifikasi tindakan-tindakan menurut analisis konflik dan posisi seseorang di tengah konflik (Fisher, et.al, 2001). Untuk melakukan strategi memetakan jalan terbuka, hal pertama yang harus dilakukan ialah dengan membuat peta konflik. Kedua, dimana dan bagaimana seseorang memetakan hubungan diri sendiri dengan organisasi serta kelompok lainnya. Ketiga, dalam melakukan analisis terhadap peta yang dibuat, perhatikan beberapa kemungkinan jalan pembukanya, misalnya struktur-struktur yang perlu diubah atau diciptakan, isu-isu yang ingin diselesaikan, kelompok-kelompok marjinal 


\begin{tabular}{|c|c|c|c|c|}
\hline $\begin{array}{c}\text { JURNAL } \\
\text { KOLABORASI RESOLUSI KONFLIK }\end{array}$ & \multirow{2}{*}{ VOLUME 3} & \multirow{2}{*}{ NOMOR 1 } & HALAMAN 65-74 & $\begin{array}{l}\text { ISSN 2655-8823 }(p) \\
\text { ISSN 2656-1786 }(e)\end{array}$ \\
\hline
\end{tabular}

yang dapat memegang peranan positif, atau membuka komunikasi yang terhambat. Selain itu, perlu juga memperhatikan hambatan yang mungkin terjadi seperti hubungan yang rusak diantara pihak-pihak yang sebelumnya berhubungan, atau kesenjangan antara partai yang belum pernah memiliki jalur komunikasi diantara keduanya. Keempat, perlu memperhatikan komunikasi yang terjadi pada pihak yang bersangkutan. Dalam kondisi tersebut, perlu memilah siapa yang menjadi tokoh kunci pada pihak atau organisasi lain sebagai upaya dalam pemecahan masalah.

Kelima, kita perlu mengetahui struktur dan isu-isu yang ada dalam proses menyusun strategi konflik. Struktur tersebut apakah merupakan struktur yang berbeda (mungkin kelompok antarparlemen atau komite yang mengarahkan pembangunan masyarakat). Sedangkan mengenai isu-isu, kita perlu mengetahui apakah terdapat isu-isu yang sama sekali belum teratasi? Hal ini perlu dilakukan suatu rangkaian pertemuan untuk melakukan diskusi bersama warga masyarakat, atau mengundang pembicara ahli dari luar negeri untuk memimpin diskusi panel melalui radio, atau menerbitkan buku komik untuk mengajak orang turut memikirkan isu tersebut.

\section{HASIL DAN PEMBAHASAN}

Sebagai upaya pemerintah dalam menangani Covid-19, pemerintah memiliki kekuatan atas kekuaasaan dalam peranannya. Kementrian Sosial RI turut andil dalam upaya penanganan Covid-19 di Indonesia. Kementrian Sosial RI memiliki otoritas (posisi) sebagai sumber kekuasaan yang didukung oleh peraturan, norma, dan sumber daya. Dalam hal ini, Kementrian Sosial RI dalam kekuasaanya membuat kebijakan program bantuan sosial bagi masyarakat yang terdampak Covid-19. Selain itu, Kementrian Sosial RI memiliki akses kepada sumber daya atas pemberian bantuan sosial kepada masyarakat berupa bahan baku makanan kepada masyarakat untuk mempertahankan hidup karena kemiskinan yang diakibatkan oleh pandemi Covid-19. Kekuasaan ini juga dapat menjadi sebab terjadinya konflik yang terjadi antara pemerintah dengan masyarakat. Sebagai pemilik kekuatan atas kekuasaan, tentu tidak mudah dalam melakukan peranannya. Kekuasaan yang ada dapat disalahgunakan demi kepentingan pribadi dengan tidak memperdulikan kondisi dan situasi saat tertentu, termasuk pada saat kondisi pandemi Covid-19 sekarang.

Analisis terhadap konflik di tengah pandemi Covid-19 ini dapat dilihat dalam dua tipe yaitu tipe konflik vertikal dan tipe konflik horizontal. Konflik vertikal merujuk pada konflik yang terjadi antara masyarakat dengan pemerintah atau yang melibatkan unsur pemerintah dengan semua bentuk aparaturnya, sedangkan tipe horizontal merujuk pada konflik yang terjadi antar masyarakat sendiri atau ketika masyarakat bertikai antara mereka sendiri. Hal ini sebagaimana dilihat dari siapa aktor yang berperan dalam konflik tersebut.

Tipe konflik vertikal dalam hal ini ialah terkait dengan distibusi bantuan sosial yang diberikan oleh pemerintah, baik pusat maupun daerah kepada masyarakat. Sumber konflik ini secara khusus merujuk pada distribusi bantuan sosial tersebut yang tidak merata dan tidak tepat sasaran. Selain itu, terdapat juga penyelewengan akibat bantuan sosial yang diterima oleh warga dalam kondisi sudah busuk (Sindonews, 2020). Konflik lainnya, ada sejumlah pejabat yang sedang menjalani pemeriksaan oleh Komisi Pemberantasan Korupsi (KPK) terhadap sejumlah pejabat salah satunya ialah Menteri Sosial RI yaitu Juliari P Batubara yang tersandung kasus suap bantuan sosial (Tribunews, 2020). Selain itu, KPK juga menjalani pemeriksaan terhadap pejabat di Lingkungan Pemerintah Kabupaten Bandung Barat (KBB) diduga berkaitan dengan penyelidikan kasus bantuan sosial Covid-19 (Kompas.com, 2020). Hal ini menyebabkan timbulnya kekecewaan, protes, dan ketidakpuasan masyarakat 


\begin{tabular}{|c|c|c|c|c|}
\hline JURNAL & \multirow{2}{*}{ VOLUME 3} & \multirow{2}{*}{ NOMOR 1 } & HALAMAN 65-74 & $\begin{array}{l}\text { ISSN 2655-8823 }(p) \\
\text { ISSN 2656-1786 }(e)\end{array}$ \\
KOLABORASI RESOLUSI KONFLIK & ISS \\
\hline
\end{tabular}

kepada pemerintah dalam program bantuan sosial.

Sedangkan tipe konflik horizontal yaitu adanya bentuk penolakan dari masyarakat atas penguburan jenazah Covid-19 di wilayahnya. Akibat terus meningkatnya kasus positif di Indonesia, pemerintah pusat dan daerah serta lembaga masyarakat dan tokoh agama pun ikut turun tangan untuk memberikan edukasi mengenai Covid-19 dan meredakan konflik tersebut. Salah satu contoh kasus penolakan penguburan jenazah Covid-19 dan juga menjadi banyak perhatian adalah yang terjadi di Kecamatan Solokanjeruk, Kabupaten Bandung (Ayobandung, 2020). Selain itu, konflik selanjutnya ialah adanya penolakan oleh masyarakat atas tenaga medis Covid-19 untuk tinggal atau menetap di sekitar wilayah mereka atau mengucilkan mereka jika tetap tinggal di wilayahnya. Salah satu contohnya terdapat 52 perawat Rumah Sakit Hasan Sadikin (RSHS) yang tinggal sementara di UPTD Pelatihan Kesehatan (Upelkes) Dinkes Jabar yang mengalami kondisi sosial penolakan di wiliayahnya (Detiknews, 2020).

\section{Analisis Pohon Konflik}

Berdasarkan pada pemahaman tersebut, dalam artikel ini disajikan hasil analisis konflik pada distribusi bantuan sosial Covid-19 yang diberikan oleh pemerintah kepada masyarakat dengan menggunakan alat bantu pohon konflik. Adapun analisis konflik dengan menggunakan pohon konflik dapat dijelaskan melalui gambar berikut ini:

Gambar 1. Analisis Pohon Konflik

Distribusi Bantuan Sosial Covid-19

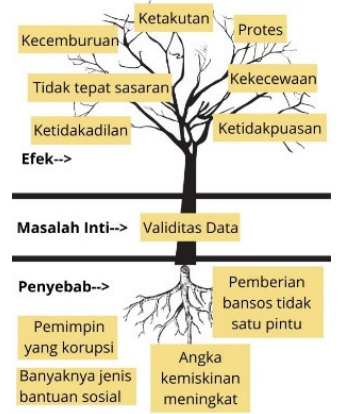

Berdasarkan Gambar 1. diatas, kita dapat mengetahui mengenai analisis konflik dengan menggunakan pohon konflik pada distribusi bantuan sosial Covid-19 yang diberikan oleh pemerintah, baik pusat maupun daerah. Pohon konlik dapat berguna dalam memetakan permasalahan yang timbul pada proses distribusi bantuan sosial Covid-19. Dalam hal ini, dapat diketahui apa yang menjadi masalah inti, penyebab dari masalah tersebut, dan efek yang ditimbulkan dari masalah yang ada.

Pertama, penulis akan mengkaji mengenai permasalahan inti pada konflik distribusi bantuan sosial Covd-19 ini adalah adanya ketidaksesuaian data atau validitas data yang dimiliki oleh pemerintah, baik pusat maupun daerah. Hal ini tentu sangat krusial dan patut dijadikan perhatian serta pengkajian ulang mengenai data-data masyarakat yang berhak mendapat bantuan sosial. Pemerintah perlu mulai memperbaharui data yang ada dan dapat dimulai dari tingkat Rukun Tetangga (RT) setempat. Pencatatan ini perlu juga dilakukan survey ke lapangan untuk melihat kesesuaian data dan kriteria tertentu yang telah ditentukan oleh pemerintah sebagai sasaran penerima manfaat. Masyarakat juga harus dituntut untuk melaporkan anggota keluarganya baik yang masih hidup atau yang sudah meninggal serta bagi masyarakat yang berpindah tempat tinggal karena tentu hal ini sangat mempengaruhi data dalam memberikan bantuan sosial.

Kedua, mengkaji mengenai penyebab dari timbulnya konflik distribusi bantuan sosial Covd-19 ini yaitu diantaranya:

a. Adanya penyelewengan dana bantuan sosial Covid-19 oleh sejumlah pejabat untuk meraih keuntungan sendiri dengan tidak memikirkan kondisi masyarakatnya di tengah pandemik Covid-19. Dana yang seharusnya digunakan sebagai bantuan kepada masyarakat, dipakai untuk kepentingan diri sendiri. Hal 


\begin{tabular}{|c|c|c|c|c|}
\hline $\begin{array}{c}\text { JURNAL } \\
\text { KOLABORASI RESOLUSI KONFLIK }\end{array}$ & VOLUME 3 & \multirow{2}{*}{ NOMOR 1 } & HALAMAN 65-74 & $\begin{array}{l}\text { ISSN 2655-8823 }(p) \\
\text { ISSN 2656-1786 }(e)\end{array}$ \\
\hline
\end{tabular}

ini menyebabkan besanya bantuan dana yang diberikan kepada masyarakat tidak sesuai dengan yang sudah ditentukan.

b. Banyaknya jenis bantuan sosial yang berasal dari pemerintah, baik pusat maupun daerah, bantuan sosial yang diterima oleh masyarakat menjadi saling tumpah tindih. Dari sekian banyaknya jenis bantuan sosial, kepala daerah dan juga RT atau RW setempat saling kebingungan karna terjadi perbedaan bantuan sosial satu dengan yang lainnya. Misalnya A mendapatkan bantuan sosial dari presiden sedangkan B mendapat bantuan sosial dari Bupati setempat. Hal ini tentu dapat menimbulkan kecemburuan antar masyarakat, kekecewaan, protes, dan lain sebagainya karna item (barang sembako) yang diberikan dapat berbeda jenisnya.

c. Angka kemiskinan di Indonesia semenjak terjadi pandemik Covid19 meningkat. Dilansir pada (Suara.com, 2020) menunjukkan adanya peningkatan jumlah penduduk miskin sebesar 1,63 juta orang dari 24,79 juta orang pada bulan September 2019 menjadi 26,42 juta orang pada Maret 2020. Peningkatan jumlah penduduk miskin ini disebabkan adanya permasalahan pandemi Covid-19 yang sampai saat ini belum menunjukkan tren penurunan. Hal ini disebabkan pula karena banyaknya karyawan yang terkena PHK oleh sejumlah perusahaan yang kemudian menyebabkan banyaknya masyarakat yang masuk dalam kategori miskin baru. Ini juga yang menjadi penyebab ketidaksesuaian data yang ada di pemerintah, baik pusat maupun daerah, dengan kondisi di lapangan. d. Pemberian bantuan sosial tidak satu pintu ini dikarenakan pemerintah, baik pusat maupun daerah menggunakan anggaran APBD pada saat pandemik Covid-19 ini difokuskan untuk pemberian bantuan sosial bagi masyarakat yang terdampak Covid-19. Selain itu, ada juga LSM atau organisasi yang memberikan bantuan sosial kepada masyarakat secara sukarela dengan tidak melihat keluarga mana yang sangat membutuhkan bantuan tersebut.

Ketiga, mengkaji mengenai efek dari timbulnya konflik distribusi bantuan sosial Covd-19 ini kepada masyarakat adalah adanya rasa ketidakadilan, kekecewaan, kecemburuan sosial, ketakutan, protes, ketidakpuasan, dan bantuan sosial menjadi tidak tepat sasaran pada masyarakat. Hal ini apabila terus dibiarkan maka akan menimbulkan permasalah yang lain seperti kekerasan, kriminalitas, dan lain-lain. Ini juga bisa berdampak pada ketidakpercayaan masyarakat kepada pemerintah dalam menangani pandemik Covid-19 di Indonesia. Dengan adanya berbagai kebijakan yang dibuat oleh pemerintah, masyarakat juga berharap agar dalam kondisi pandemik Covid-19 pemerintah dapat bersikap adil dan memperhatikan masyarakat mengingat banyaknya karyawan yang terkena PHK, sektor pekerja informal menjadi sulit bekerja, dan dampak lain yang menyebabkan masyarakat mengalami penurunan selama pandemik Covid-19.

\section{Memetakan Jalan Pembuka sebagai Strategi Mengelola Konflik}

Setelah menganalisis dari adanya konflik distribusi bantuan sosial Covd-19 ini, perlu juga untuk menyusun strategi dalam mengelola konflik distribusi bantuan sosial Covid-19. Dalam strategi memetakan jalan terbuka, berikut peta konflik: 


\begin{tabular}{|c|c|c|c|c|}
\hline JURNAL & \multirow{2}{*}{ VOLUME 3} & \multirow{2}{*}{ NOMOR 1 } & HALAMAN 65-74 & $\begin{array}{l}\text { ISSN 2655-8823 }(p) \\
\text { ISSN 2656-1786 }(e)\end{array}$ \\
KOLABORASI RESOLUSI KONFLIK & ISS \\
\hline
\end{tabular}

Gambar. 2 Memetakan Jalan Pembuka

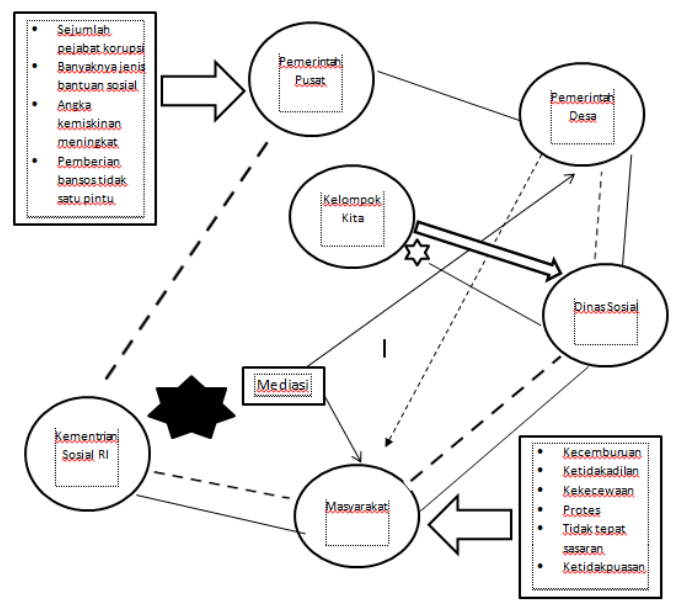

Kunc1:

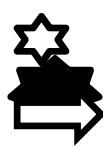

Pilihan untuk jalan pembuka

Titik pemecahan

Langkah pertama lakukan kontak dengan dinas sosial

$\rightarrow-\rightarrow$ Langkah kedua lakukan kontak kepada pemerintah desa dan pendekatan kepada masyarakat

- - - Langkah ketiga mengumpulkan perwakilan dari pemerintah desa, dinas sosial, dan kementrian sosial $\mathrm{RI} /$ bangun kepercayaan/negosiasi

Berdasarkan gambar diatas, terdapat pilihan untuk jalan pembuka sebagai strategi dalam penyelesaian konflik yaitu antara dinas sosial dengan kelompok kita (individu/kelompok/organisasi yang membantu dalam penyelesaian konflik) mengenai data-data masyarakat yang terdampak oleh Covid-19. Mengetahui bagaimana data-data tersebut berasal dan syarat-syarat sebagai penerima bantuan sosial Covid-19. Hal tersebut kemudian diteruskan kepada setiap pemerintah desa dibawah RW dan RT setempat dalam memberikan data-data yang valid mengenai siapa saja orang yang berhak mendapatkan bantuan sosial Covid-19. Selanjutnya, langkah kedua dengan melakukan kontak kepada pemerintah desa untuk mendata secara benar dan dapat melihat keadaan nyata seperti kondisi di lapangan oleh RW dan RT setempat dan pendekatan kepada masyarakat bahwa bantuan sosial hanya diberikan kepada keluarga yang termasuk ke dalam kriteria penerima manfaat bantuan sosial Covid-19. Tidak memanipulasi data dengan alasan apapun. Terakhir, langkah ketiga yaitu adanya diskusi dari perwakilan dari pemerintah desa, pemerintah daerah, dinas sosial, bersama Kementrian Sosial RI mengenai regulasi, peraturan, dan sistem pendistribusian bantuan sosial Covid-19 agar hal tersebut dapat sampai kepada masyarakat yang sebagai penerima manfaat yang sesuai dengan kebijakan dan tujuan yang telah ditetapkan oleh pemerintah.

\section{KESIMPULAN DAN SARAN}

Kesimpulan

Pelaksanaan program bantuan sosial bagi masyarakat terdampak Covid-19 menghadapi masalah khususnya pada distribusi bantuan sosial Covid-19 yang tidak tepat sasaran, sebagian masyarakat yang termasuk kedalam kelompok Rumah Tangga Sasaran (RTS) tidak menerima bantuan sosial sedangkan yang bukan Rumah Tangga Sasaran (RTS) justru mendapatkan bantuan sosial. Hal ini tentu mendapat banyak reaksi kekecewaan pada masyarakat terhadap pemerintah karena ketidaksesuaian distribusi bantuan sosial Covid-19.

Dalam memetakan konflik yang ada, untuk memudahkan dalam memahami masalah yang ada digunakanlah alat bantu pohon konflik untuk mengetahui apa yang menjadi masalah inti, penyebab dan efek dari konflik distribusi bantuan sosial Covid19. Selain itu, untuk menyelesaikan konflik tersebut, pelru adanya strategi yang digunakan sebagai upaya dalam menangani konflik tersebut. Perlu adanya analisis terlebih dahulu serta mengetahui individu, kelompok, atau organisasi yang saling berhubungan dan mempengaruhi dengan adanya konflik tersebut. Dalam konflik ini, strategi yang digunakan dalam mengelola konflik yaitu dengan memetakan jalan terbuka dengan menyusun strategi pihak mana yang terlibat dan langkah apa saja yang dapat dilakukan sebagai upaya pemecahan konflik. Selain itu adanya 


\begin{tabular}{|c|c|c|c|c|}
\hline JURNAL & \multirow{2}{*}{ VOLUME 3} & \multirow{2}{*}{ NOMOR 1 } & HALAMAN 65-74 & $\begin{array}{l}\text { ISSN 2655-8823 }(p) \\
\text { ISSN 2656-1786 }(e)\end{array}$ \\
KOLABORASI RESOLUSI KONFLIK & ISS \\
\hline
\end{tabular}

upaya melakukan kontak, mediasi, dan membangun kepercayaan sebagai bentuk tanggung jawab pemerintah kepada rakyatnya.

\section{Saran}

Pemerintah pusat diharapkan lebih sering mengupdate data-data kependudukan yang bekerja sama dengan pemerintah daerah dalam memberikan pelayanan sosial agar hal-hal tersebut tidak menjadi masalah dikemudian hari. Masyarakat juga diwajibkan melaporkan kepada dinas kependudukan dan pencatatan sipil mengenai anggota keluarganya baik yang masih hidup atau sudah meninggal karena ini juga mempengaruhi besaran bantuan sosial yang diberikan kepada masyarakat.

\section{DAFTAR PUSTAKA}

Ayobandung. (2020). Polisi Selidiki Penolakan Jenazah Covid-19 di Kabupaten Bandung. Dalam: https:/ayobandung.com/read/2020/04/ 27/87396/polisi-selidiki-penolakanjenazah-covid-19-di-kabupatenbandung diakses pada 2 Desember 2020

CNN Indonesia. (2020). Kekacauan Bansos Corona, Masalah Klasik Big Data. Dalam:

https://www.cnnindonesia.com/nasiona 1/20200508133813-20-

501305/kekacauan-bansos-coronamasalah-klasik-big-data diakses pada 27 November

Detiknews. (2020). Miris! Sejumlah Paramedis Corona di Jabar Mendapat Penolakan Sosial. Dalam https://news.detik.com/berita-jawabarat/d-4958285/miris-sejumlahparamedis-corona-di-jabar-mendapatpenolakan-sosial diakses pada 2 Desember 2020

Fisher, Simon, dkk., 2001, Mengelola Konflik: Keterampilan dan Strategi untuk Bertindak, The British Council Indonesia, Jakarta.

Herdiana, D. (2020). Pengawasan Kolaboratif dalam Pelaksanaan
Kebijakan Bantuan Sosial Terdampak Covid-19. Jurnal Dinamika Pemerintahan, 3(2).

Kemendikbud. (2020). Mendikbud Terbitkan SE tentang Pelaksanaan Pendidikan dalam Masa Darurat Covid19. Diakses pada 27 November 2020 dalam:

https://www.kemdikbud.go.id/main/blo $\mathrm{g} / 2020 / 03 /$ mendikbud-terbitkan-setentang-pelaksanaan-pendidikandalam-masa-darurat-covid19

Kumparan.com. (2020). Ini Bukti Data Kasus Corona Masuk Indonesia Sejak Akhir Januari 2020. Diakses dalam: https://kumparan.com/kumparansains/i ni-bukti-data-kasus-corona-masukindonesia-sejak-akhir-januari-20201 tGgkxIsKap/full

Kompas.com. (2020). Penyelidikan KPK di Bandung Barat Terkait Bansos Covid$19 ?$.

Dalam https://ayobandung.com/read/2020/11/ 17/153738/penyelidikan-kpk-dibandung-barat-terkait-bansos-covid-19 diakses pada 1 Desember 2020

Mufida, A. (2020). Polemik Pemberian Bantuan Sosial Di Tengah Pandemic Covid 19. 'ADALAH, 4(1).

Rahmansyah, W., Qadri, R. A., Sakti, R. R. A., \& Ikhsan, S. (2020). Pemetaan Permasalahan Penyaluran Bantuan Sosial Untuk Penanganan Covid-19 di Indonesia. Jurnal PKN (Jurnal Pajak dan Keuangan Negara), 2(1), 90-102.

Pikiran Rakyat Bandung Raya. (2020). Data Warga Miskin Penerima Bansos Covid-19 Tumpang Tindih, Disnosnangkis Bandung Gencar Validasi. Dalam:

https://prbandungraya.pikiranrakyat.com/kota-bandung/pr26855363/data-warga-miskinpenerima-bansos-covid-19-tumpangtindih-disnosnangkis-bandung-gencarvalidasi diakses pada 1 Desember 2020 


\begin{tabular}{|c|c|c|c|c|}
\hline JURNAL & \multirow{2}{*}{ NOLUME 3} & \multirow{2}{*}{ NOMOR 1} & HALAMAN 65-74 & $\begin{array}{l}\text { ISSN 2655-8823 }(p) \\
\text { ISSN 2656-1786 }(e)\end{array}$ \\
\hline
\end{tabular}

Sindonews. (2020). Sembako Busuk di Bandung Barat Terus Bergulir. Dalam: https://daerah.sindonews.com $/ \mathrm{read} / 230$ 158/701/kasus-bansos-covid-19sembako-busuk-di-bandung-baratterus-bergulir-1605193911 diakses pada 1 Desember 2020

Susilo, A., Rumende, C. M., Pitoyo, C. W., Santoso, W. D., Yulianti, M., Herikurniawan, H., \& Chen, L. K. (2020). Coronavirus Disease 2019: Tinjauan Literatur Terkini. Jurnal Penyakit Dalam Indonesia, 7(1), 45-67. Suara.com. (2020). Peningkatan Angka Kemiskinan di Tengah Pandemi yang Tak Kunjung Selesai. Dalam: https://yoursay.suara.com/news/2020/0 7/27/112331/peningkatan-angkakemiskinan-di-tengah-pandemi-yangtak-kunjung-selesai diakses pada 4 Desember 2020

TribunTernate.com. (2020). Update Sebaran Virus Corona Indonesia Kamis (26/11/2020): DKI Catat 1.064 Kasus Baru \& 1.125 Sembuh. Dalam: https://ternate.tribunnews.com/2020/11 /26/update-sebaran-virus-coronaindonesia-kamis-26112020-dki-catat1064-kasus-baru-1125-sembuh diakses pada 27 November 2020

Tribunews. (2020). Breaking News: Menteri Sosial Juliari Batubara Resmi di Tahan KPK. Dalam https://www.tribunnews.com/nasional/ 2020/12/06/breaking-news-menterisosial-juliari-batubara-resmi-ditahankpk. Diakses pada 12 Desember 2020

Yuliana, Y. (2020). Corona Virus Diseases (Covid-19): Sebuah Tinjauan Literatur. Wellness And Healthy Magazine, 2(1), 187-192. 